\title{
Donor Lymphocytes
}

National Cancer Institute

\section{Source}

National Cancer Institute. Donor Lymphocytes. NCI Thesaurus. Code C91712.

A population of lymphocytes from the blood of a donor and administered to a patient who has already received a stem cell transplant from the same donor (Allogeneic Hematopoietic Stem Cell T ransplantation). The donor lymphocytes may be able to boost the patient's immune system and kill remaining cancer cells. 